Proc. Estonian Acad. Sci. Geol., 2005, 54, 1, 52-68

\title{
Palynostratigraphy of Holocene lake sediments on the Otepää Heights, southern Estonia
}

\begin{abstract}
Mihkel Kangur
Institute of Ecology at Tallinn Pedagogical University, Kevade 2, 10137 Tallinn, Estonia; mihkel@eco.edu.ee

Received 3 November 2004, in revised form 24 January 2005

Abstract. The pollen diagram with accelerator mass spectrometer (AMS) radiocarbon dates covering Holocene sediments from the Otepää Heights gives a general overview of the vegetation history of the area. The pollen assemblage zones (PAZs) defined on the pollen diagram of the Lake Väike Juusa core in general correspond to the PAZs on the stratigraphic chart of Holocene sediments in Estonia. Comparison of the pollen profile of Lake Väike Juusa with other pollen diagrams from the same area enables us to distinguish differences in the vegetation history induced by local factors. The most characteristic differences occur in the Picea pollen content. Picea migrated to the Otepää Heights in small patches already at the end of the Boreal Chronozone and started to spread at the end of the Atlantic Chronozone. This is about 1000 years earlier than shown in the Holocene stratigraphic chart of Estonia. Also human activity and forest fires in the areas surrounding the study sites have affected the vegetation dynamics on a local scale during the last two millennia.
\end{abstract}

Key words: pollen, palynostratigraphy, vegetation history, forest fires, southern Estonia.

\section{INTRODUCTION}

The Otepää Heights are interesting from the geological, geographical, and archaeological aspects. The area is characterized by the distribution and genesis of various landforms, caused by the bedrock structure and accumulation processes. As the variety of landforms is high, also the vegetation is variable, and the vegetation history of the area has been influenced by different processes and local factors. Small lakes located on the bottoms of small valleys provide an opportunity to study the vegetation history on a local scale (Jacobson \& Bradshaw 1981). Pollen-vegetation relationships have been studied for decades (Tauber 1965; Andersen 1970; Janssen 1973; Kabailene 1979), and numerous theoretical models have been developed for this purpose (Davis 1963; Andersen 1970; Parsons \& Prentice 1981; Prentice \& Parsons 1983; Jackson 1990). In order to improve 
previous models, Sugita (1994) introduced the concept of the "relevant source area of pollen", defined as the distance beyond which the correlation between pollen deposited at a site and the surrounding vegetation does not improve. Theoretical models and some empirical studies (Koff et al. 2000; Kangur 2002) show that the relevant source area of pollen of Estonian small lakes (3-6 ha) is a some hundred metres wide belt around the lake. The changes in vegetation must embrace at least $25 \%$ of the relevant source area of pollen to be reliably detected on pollen diagram (Sugita 1994, 1998; Koff et al. 2000). In the present study the 200-300 m wide belt around the lake is defined as the area where changes in vegetation on a local scale take place.

In this paper a pollen diagram from Lake Väike Juusa (hereafter L. Juusa) sediments is presented and the results are compared with other pollen profiles from the same region. One pollen diagram is available from an overgrown lake $1 \mathrm{~km}$ NE of Otepää (hereafter Otepää profile) (Sarv 1979). The pollen profile from Lake Ala-Pika sediments (Kihno 1998; Kihno \& Valk 1999) does not cover the Holocene deposits entirely. For correlations the stratigraphic chart of the Late-Glacial and Holocene of Estonia (Raukas et al. 1995) was used. Lake Juusa, Otepää site, and L. Ala-Pika lie close to each other (Fig. 1). The distance between

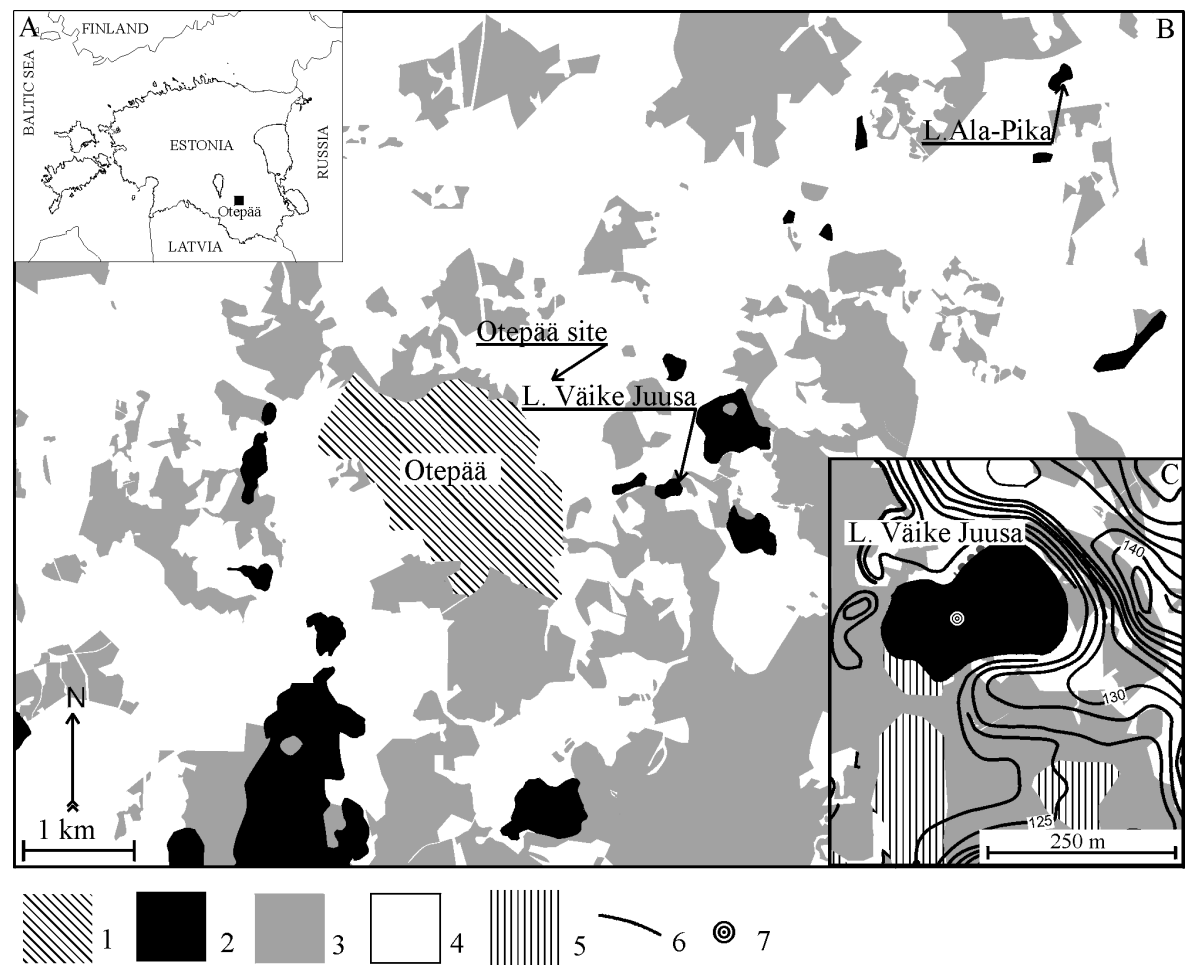

Fig. 1. Location of the study area (A), Lake Väike Juusa and reference cores (B), and the studied core (C). Legend: 1, urban area; 2, lake; 3, forest; 4, open area; 5, mire; 6, isoline; 7, studied core. 
L. Juusa and L. Ala-Pika is about $6 \mathrm{~km}$. Both lakes are of similar size (L. Juusa 3 ha; L. Ala-Pika - 2.5 ha) and shape. The Otepää core was taken from the bottom of an overgrown lake, $1 \mathrm{~km}$ northeast of Otepää and ca $1.5 \mathrm{~km}$ north of L. Juusa. Lake Juusa is located in the central part of the Otepää Heights, where relative altitude is $50-60 \mathrm{~m}$. Also the Otepää core was taken from the central part of the Otepää Heights but from a smaller depression. Lake Ala-Pika is situated in the marginal area of the Otepää Heights, where relative altitude is 30-40 m. Differences in topography of the areas surrounding the study sites have led to a high variability in soil conditions.

Considering the size of L. Juusa ( $3 \mathrm{ha}$ ) and its position, the palynostratigraphical material from the L. Juusa core may describe the vegetation on a local scale. The main objectives of this paper were to present a palynostratigraphical characterization of L. Juusa sediments and to assess which local factors have influenced the evolution of vegetation in that area.

\section{DESCRIPTION OF THE AREA}

The Otepää Heights, delimited by a $\sim 100 \mathrm{~m}$ a.s.l. contour, are typical accumulative heights of glacial origin. The hilly landscape is formed of limnoand fluvioglacial kames and hills of complicated structure covered by solifluctional and ablation till (Raukas \& Karukäpp 1979).

In the central part of the Otepää Heights the relative altitude of the higher hills reaches 50-60 m (Hang 1979). Because of complicated landforms, the diversity of soil types is high, including eroded, erodible, deluvial, gley, and marsh soils. According to the geobotanical mapping of Estonia, the Otepää Heights belong to the region of spruce and mixed spruce forests (Laasimer 1965). Vegetation is multifarious, characterized by small mosaic patches pursuant to the landforms. Spruce and spruce-pine mixed forests are common. The depressions between the hills are occupied by minerotrophic mires with a low number of species. Agricultural lands occur mainly on the slopes of the hills. The oldest archaeological findings from the Otepää Heights are dated to the Late Mesolithic period (Kihno \& Valk 1999). The ancient Otepää stronghold is situated at a distance of $1.5 \mathrm{~km}$ to the west of L. Juusa. The stronghold, built in the 7th-8th centuries, is a clear sign of relatively dense population in this area during the last millennia.

Lake Juusa $\left(58^{\circ} 03^{\prime} \mathrm{N} ; 26^{\circ} 30^{\prime} \mathrm{E}\right)$ is located in the centre of the Otepää Heights. It is a small lake (area 3 ha, maximum length $250 \mathrm{~m}$ and width $160 \mathrm{~m}$ ) (Fig. 1), with the mean depth of $3.7 \mathrm{~m}$ and maximum depth of $5.8 \mathrm{~m}$ (in the eastern part). Juusa is a eutrophic dimictic lake, with strong stratification during spring-summer. Based on the lithological and geochemical composition of sediments, water level fluctuations during the Holocene have been reconstructed (Punning et al. in press). 
The bottom sediments are up to $12 \mathrm{~m}$ thick in the deepest part of the lake. The surface layers of sediments are brownish gyttja with a high water and organic matter content (Punning et al. in press). The drainage area of L. Juusa is 55 ha. The lake is surrounded by semi-open cultural landscape. The vegetation around the lake consists of pine forest on its western side and mixed spruce forest on the eastern side. Agriculture was well developed around the lake up to the 1990s, now there are just two farms pursuing small-scale farming south of the lake.

\section{METHODS}

The core (J20) for this study was taken in the winter of 2002 from the central part of the lake where the water depth was $5 \mathrm{~m}$ (Fig. 1). The upper layers of lake sediments $(50 \mathrm{~cm})$ were sampled using a modified Livingstone-Vallentyne piston corer (diameter $7 \mathrm{~cm}$ ). Sediments from $50 \mathrm{~cm}$ below the sediment surface down to the mineral bottom were sampled with a Belorussian peat sampler. Coring from a stable ice cover and precise measurement of the depth of the coring point ensured that the upper layers of the sediment were not disturbed. The lithology of the sediments was described in the field immediately after coring. Samples were wrapped in plastic and kept in the refrigerator prior to analysis.

For pollen and charcoal analysis $1 \mathrm{~cm}^{3}$ samples were taken after every $20 \mathrm{~cm}$. Because of signs of possible forest fires, samples from a $250-260 \mathrm{~cm}$ depth were taken continuously after every centimetre. At depths from 885 to $953 \mathrm{~cm}$, samples were taken after every $5 \mathrm{~cm}$.

Wet samples were boiled in $10 \% \mathrm{KOH}$ and acetolysed following standard procedures (Moore \& Webb 1978). The samples were not sieved at any stage of the preparation. Three tablets containing a known number of Lycopodium spores were added to each sample at the beginning of treatment, thus enabling the calculation of charcoal concentrations (Stockmarr 1971). Generally all pollen grains and spores were counted to at least 500 arboreal pollen (AP) grains per level. Pollen percentages were calculated using the sum of terrestrial pollen grains (sum of AP and non-arboreal pollen (NAP)). Spores and pollen of aquatic vegetation were also counted. The pollen diagram of L. Juusa has been divided into local pollen assemblage zones (PAZs) based on the AP content.

Charcoal particles larger than $100 \mu \mathrm{m}^{2}$ were counted on the pollen slides. The area of every charcoal particle was estimated by multiplying the lengths of the longest and shortest axes. Subsequently the total area of charcoal $\left(\mu \mathrm{m}^{2} \mathrm{~cm}^{-3}\right.$ sediment) was calculated.

The L. Juusa core was accelerator mass spectrometer (AMS) radiocarbon dated on macrofossils in the Institute of Physics, Erlangen-Nürnberg University, Germany. 


\section{RESULTS}

\section{Lithostratigraphy of lake sediments}

Holocene lacustrine sediments are lying on Late-Glacial clayey silt. The thickness of the Holocene lake sediments at the coring point is about $10 \mathrm{~m}$. Gyttja in L. Juusa is rich in organic matter (30-70\%). The carbonate content varies from 10 to $35 \%$, also fragments of mollusc shells are found in some sediment layers (Punning et al. in press). The sediment description is given in Table 1.

\section{Radiocarbon dates}

Because of the high carbonate content of lake sediments, the chronological control for the sediment records was achieved through AMS radiocarbon dating of terrestrial plant macrofossils. The terrestrial macrofossils, such as seeds of Betula, wood pieces, etc., were separated from the sediments in the laboratory by sieving. The results of AMS radiocarbon dating are given in Table 2. Based on AMS ${ }^{14} \mathrm{C}$ dates, an age-depth curve was drawn (Fig. 2).

Table 1. Lithostratigraphy of Lake Juusa bottom sediments

\begin{tabular}{cl}
\hline Depth, cm & \\
\hline $0-180$ & Colloidal dark brown gyttja. Fragments of mollusc shells \\
$180-260$ & Calcareous gyttja, rich in plant remains \\
$260-380$ & Detritus gyttja, reddish-brown. Fragments of mollusc shells \\
$380-490$ & Homogeneous gyttja, brown \\
$490-590$ & Homogeneous gyttja, light grey \\
$590-750$ & Calcareous gyttja. Fragments of mollusc shells \\
$750-850$ & Homogeneous gyttja. Fragments of mollusc shells, and gravel grains \\
$850-1000$ & Clayey gyttja \\
$1000+$ & Laminated clayey silt
\end{tabular}

Table 2. Radiocarbon dates. Ages are given in both, uncalibrated and calibrated years before present (Stuiver et al. 1998). For age estimations only uncalibrated ${ }^{14} \mathrm{C}$ dates are used

\begin{tabular}{l|l|c|c|c|c}
\hline $\begin{array}{c}\text { Depth from } \\
\text { sediment } \\
\text { surface, } \mathrm{cm}\end{array}$ & \multicolumn{1}{c|}{$\begin{array}{c}\text { Dated } \\
\text { material }\end{array}$} & $\begin{array}{c}\text { Laboratory } \\
\text { number }\end{array}$ & $\begin{array}{c}{ }^{14} \mathrm{C} \text { data, } \\
\mathrm{yr} \mathrm{BP}\end{array}$ & $\begin{array}{c}\text { Calibrated age } \\
\text { at 1 sigma, BC }\end{array}$ & $\begin{array}{c}\delta^{13} \mathrm{C}, \\
\% \text { PDB }\end{array}$ \\
\hline $454-456$ & Betula seeds & Erl-5812 & $5197 \pm 64$ & $(4218-3943)$ & -28.1 \\
$773-775$ & Betula wood & Erl-5813 & $6923 \pm 68$ & $(5869-5726)$ & -29.0 \\
$876-877$ & Betula seeds & Erl-5814 & $7909 \pm 72$ & $(7029-6655)$ & -26.5 \\
$923-925$ & Wood remains & Erl-5815 & $8910 \pm 90$ & $(8237-7945)$ & -26.2
\end{tabular}




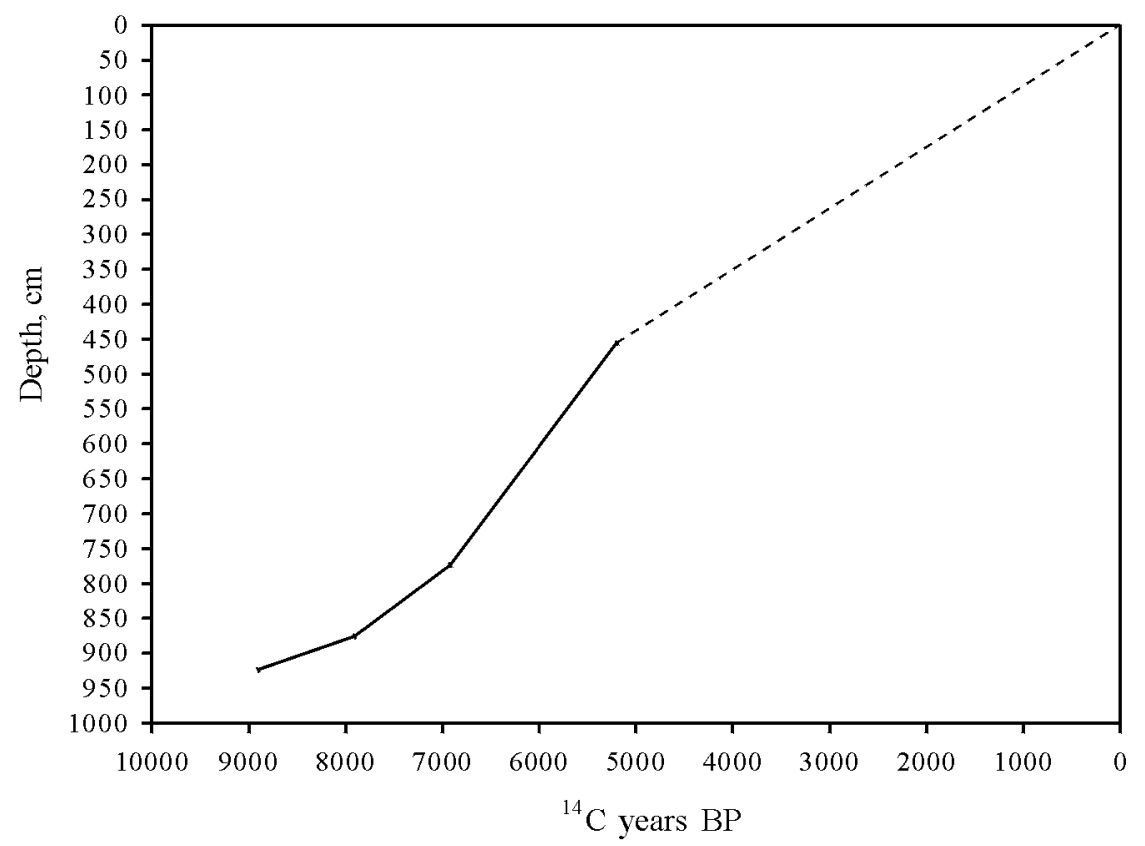

Fig. 2. Age-depth curve of the Lake Väike Juusa core.

\section{Palynostratigraphy}

The pollen diagram of L. Juusa (Fig. 3) has been divided into seven local PAZs. The PAZs are distinguished mainly on the basis of the AP content.

\section{JU1, 1035-970 cm}

The zone is distinguished by four lowermost samples, where the proportion of NAP in the pollen spectra is up to $75 \%$. Artemisia (up to 50\%) and Chenopodiaceae (up to 25\%) pollen is dominating. Also Poaceae (up to 10\%) and Helianthemum (up to 20\%) pollen was found. Filipendula pollen grains are present in small quantities. The AP is dominated by Betula (up to 35\%) and Pinus (up to 25\%). Also Salix and some Picea pollen grains were found.

\section{JU2, 969-912 cm}

The zone is distinguished by 10 samples where Betula pollen is dominating (up to 95\%). At the beginning of the zone also large quantities of Pinus pollen (up to $30 \%$ ) were found. In the central part of the zone its proportion decreases to $5 \%$, and at the end of the zone increases again to 30\%. Each sample of this zone contains small quantities of Picea pollen. In the middle of the zone Alnus and at the end of the zone also some grains of Ulmus, Corylus, and Quercus pollen appear. NAP values decrease at the beginning of the zone below $1 \%$ level. Poaceae pollen grains were present in every sample. Small quantities of Artemisia 


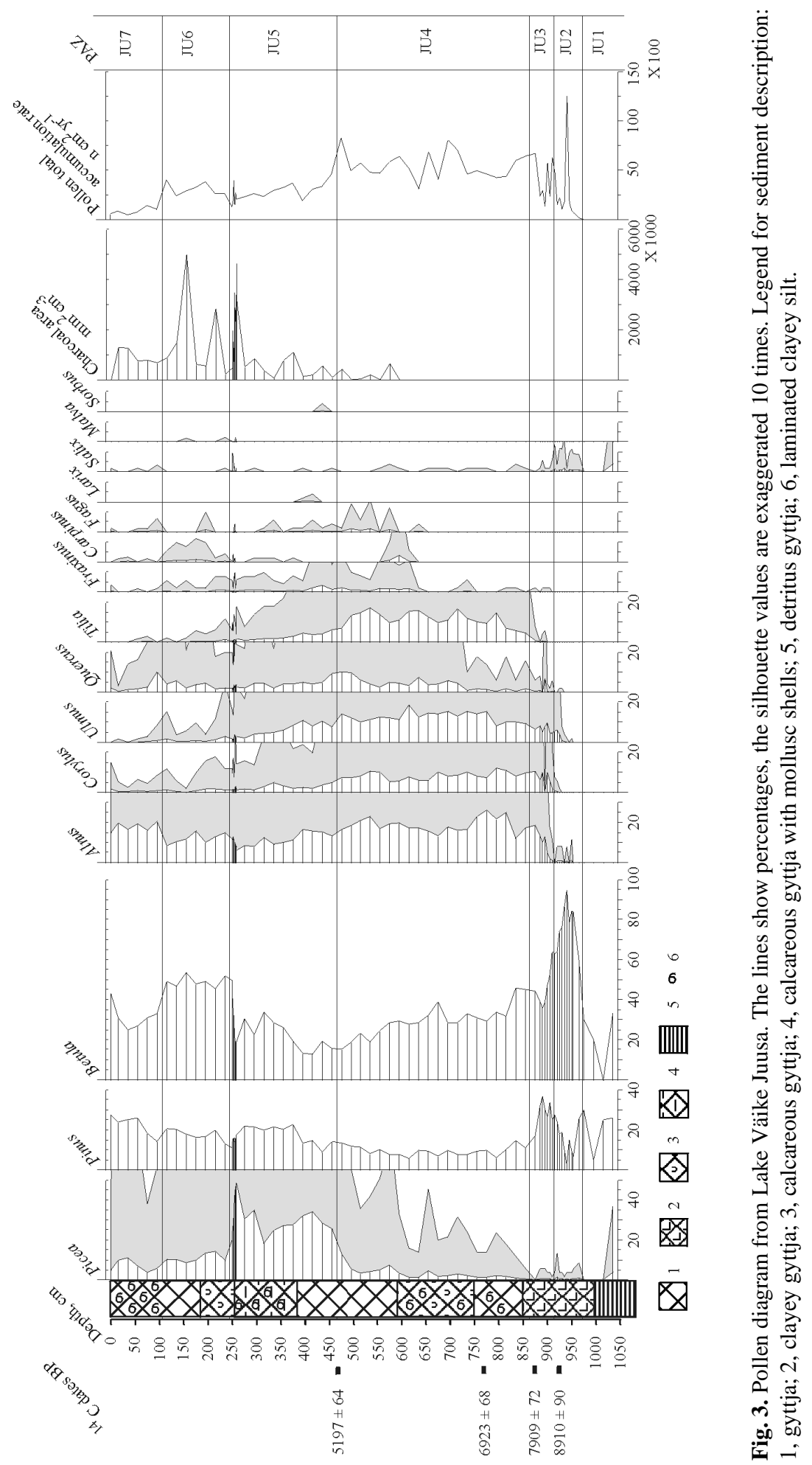




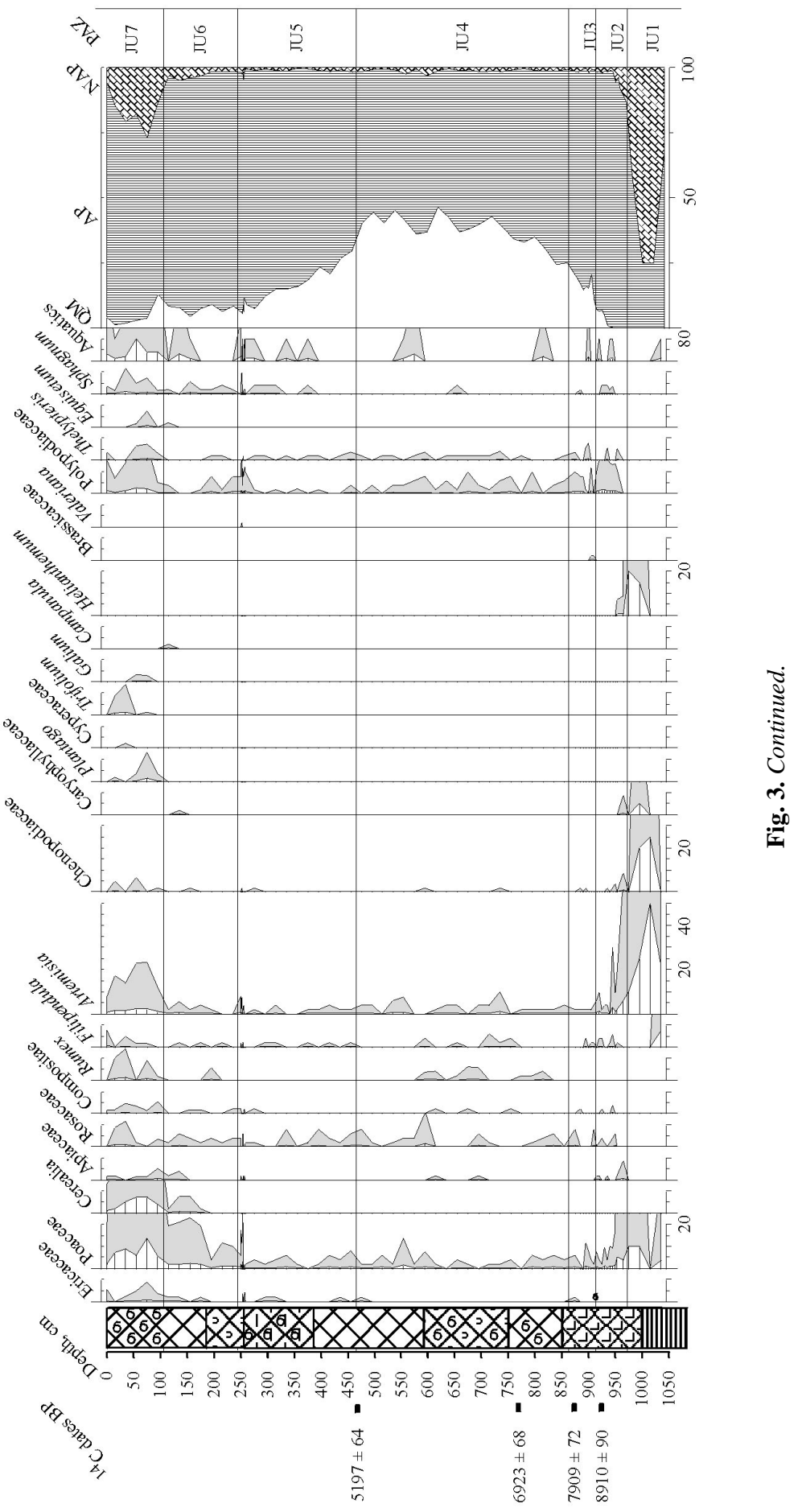


pollen grains were found. Apiaceae, Rosaceae, Compositae, and Filipendula are represented with single pollen grains. Spores of Polypodiaceae and Sphagnum appear in this zone.

\section{JU3, 911-865 cm}

The zone is distinguished by seven samples, in which Betula pollen (35-55\%) dominates. Pinus pollen reaches its maximum (35\%) in this zone. The percentage of Alnus pollen increases rapidly, at the end of the zone being above $20 \%$ level. The proportion of Corylus and Ulmus pollen increases to 10\%. Quercus pollen is found in smaller quantities. The first Tilia and Fraxinus pollen grains appear at the end of the zone. In most samples also Picea pollen is found. The percentage of Salix pollen has decreased, only some grains are found. Of herb pollen only Poaceae grains are found continuously in every sample, but their content is below $1 \%$ level. Some grains of Rosaceae, Filipendula, and Artemisia pollen are present.

\section{JU4, 864-465 cm}

The zone is distinguished by 20 samples, where pollen of thermophilous taxa, such as Tilia, Ulmus, and Quercus (Quercetum mixtum, QM), is dominating. The largest numbers of Tilia (up to 20\%) and Ulmus (up to 20\%) are found in this zone. The proportion of Corylus (up to 15\%) and Quercus (up to 10\%) pollen is smaller. Small quantities of Fraxinus, Carpinus, and Fagus pollen are also found. Over the zone the content of Betula pollen decreases from 45 to $15 \%$. At the same time the proportion of Pinus pollen increases, but it does not exceed $15 \%$. Also the percentage of Picea pollen is increasing. At the beginning of the zone Picea pollen makes up less than $1 \%$, but in the last samples of the zone, already $20 \%$. Among NAP Poaceae pollen dominates. A few grains of Apiaceae, Compositae, Rumex, Filipendula, Artemisia, and Chenopodiaceae are found. With the increase in Picea pollen the percentage of charcoal particles grows, but their total amount and area remain small until the end of the zone.

\section{JU5, 464-242 cm}

The zone is distinguished by 20 samples where Picea pollen is dominating. At the beginning of the zone the content of Picea pollen increases to $40 \%$. At the same time the proportion of Betula pollen decreases to $18 \%$. In the middle of the zone the percentage of Picea pollen decreases while that of Betula and Pinus pollen increases. At the end of the zone Picea pollen reaches its maximum (48\%). The percentage of Alnus pollen decreases over this zone. Also the percentage of QM pollen decreases rapidly. In the middle of the zone some grains of Sorbus and Larix pollen are found. At the end of the zone also some Malva pollen grains occur. The proportion of Salix pollen is low throughout the zone. The percentage of Poaceae is low, but increases markedly at the end of the zone. Other NAP grains are found rarely, only a few grains of Rosaceae, Artemisia, Compositae, Filipendula, Chenopodiaceae, and Valeriana pollen are present. The number and total area of charcoal particles increase continuously during the zone. Notably high charcoal values are recorded at the end of the zone. 


\section{JU6, 241-112 cm}

The zone (7 samples) is characterized by a high content (up to 50\%) of Betula pollen. Compared to the previous zone the percentage of Betula pollen has increased notably. The percentage of Picea pollen has decreased drastically and continues to decrease throughout the zone. The proportion of Pinus pollen does not change in this zone. Alnus pollen makes up about 10-15\%. The proportion of QM pollen is about $10-15 \%$, with Quercus pollen accounting for about $10 \%$ of this group. The content of Carpinus pollen is also relatively high (up to $2 \%$ ), while in previous samples only few grains of this pollen type were found. Some grains of Fagus pollen are present. The percentage of herb pollen increases at the end of the zone. Cerealia-type pollen appears first in the middle of the zone. Also some Apiaceae, Rosaceae, Compositae, Rumex, Filipendula, Artemisia, Chenopodiaceae, Caryophyllaceae, and Campanula pollen is found. Two maxima of the total charcoal area are distinguished, but no changes in pollen spectra can be correlated with them.

\section{JU7, $111-0 \mathrm{~cm}$}

The zone is described by six samples and characterized by a high content of NAP (15-20\%) and Alnus (20\%) pollen. Characteristic is a high proportion of Poaceae (up to 15\%) and Secale (8\%) pollen types. Artemisia pollen increases notably. Also Apiaceae, Rosaceae, Compositae, Rumex, Filipendula, Chenopodiaceae, Caryophyllaceae, Plantago, Cyperaceae, Trifolium, and Galium pollen is found. The amount of Betula pollen decreases to $25 \%$ level, but in the last samples of the zone it increases again to $45 \%$. At the beginning of the zone the content of Picea pollen decreases below $10 \%$. Also the percentage of Pinus pollen decreases at the beginning of the zone, but increases to 25 at the end of the zone. The proportion of QM pollen decreases in this zone below 5\%. The number of Polypodiaceae and Sphagnum spores has increased. A notable growth is observed also on the curve of aquatics pollen. The total area of charcoal particles is high in this zone. A marked growth occurs at the end of zone.

\section{DISCUSSION}

To find out local and regional peculiarities in palynostratigraphic data of L. Juusa, the pollen profile was compared with data of the Otepää pollen profile (Sarv 1979) and Ala-Pika pollen profiles Nos. 1 and 2 (Kihno 1998). A comparison of the pollen profiles and a stratigraphic chart of Late-Glacial and Holocene sediments in Estonia is given in Table 3. For the comparison of the Otepää and Ala-Pika palynostratigraphic data the author's zonation is used.

On the basis of the above results of pollen analyses and AMS radiocarbon dates it is possible to say that the local PAZs of the L. Juusa pollen diagram (Fig. 3) correspond rather well to chronozones of the Late-Glacial and Holocene stratigraphic chart of Estonia (Raukas et al. 1995). 
Table 3. Stratigraphy of Late-Glacial and Holocene sediments in Estonia and stratigraphic characterization of compared pollen profiles. (Legend: A, Alnus; Art, Artemisia; B, Betula; C, Corylus; Che, Chenopodiaceae; Hel, Helianthemum; NAP, Non-Arboreal Pollen; P, Pinus; Pc, Picea; Po, Poaceae; Pol, Polypodiaceae; Q, Quercus; T, Tilia; U, Ulmus)

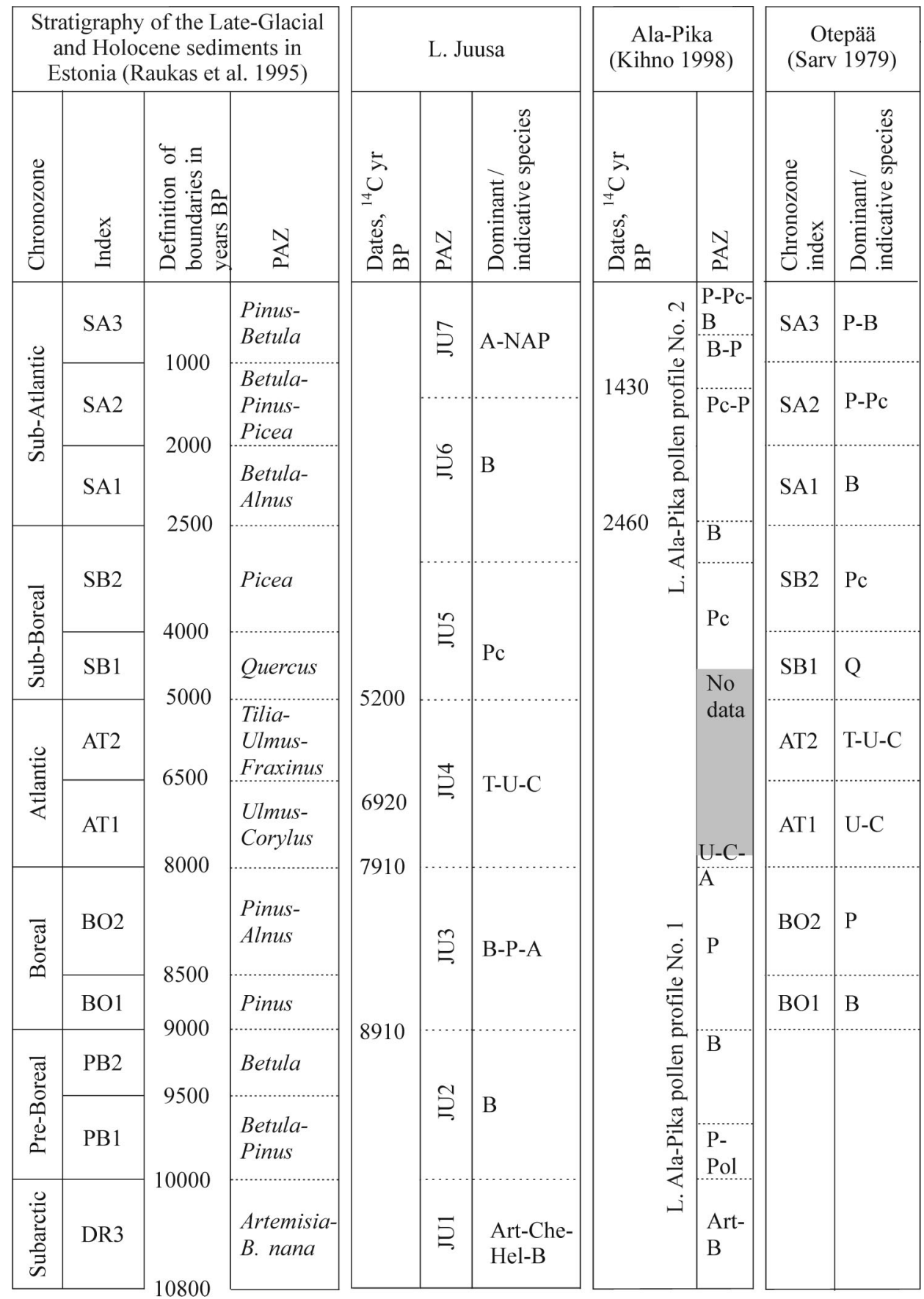


Limnic sediments started to deposit in L. Juusa at the end of the Younger Dryas. At that time mostly mineral-rich laminated clayey silt sediments, abundant in Artemisia and Chenopodiaceae pollen (JU1), deposited. Also Betula pollen grains are found. Similar pollen spectra are described in basal layers of L. Ala-Pika pollen profile No. 1. The percentage of Helianthemum pollen is extraordinarily high in the L. Juusa profile. This phenomenon has not been described in any earlier publication.

Lake Juusa pollen profile JU2 can be correlated with the Pre-Boreal Chronozone because of the decrease in the NAP pollen percentage and dominance of Betula in this zone. No Pinus pollen first maximum characterizing PB1 Chronozone is recorded at the beginning of this zone. Kihno (1998) describes the Pinus-dominated PAZ P-Pol from L. Ala-Pika pollen profile No. 1 and correlates it with PB1.

Based on the dating $\sim 8910{ }^{14} \mathrm{C}$ years $\mathrm{BP}$, the beginning of JU3 corresponds to the Boreal Chronozone. Similarly to L. Ala-Pika pollen profile No. 1, also in the L. Juusa profile Pinus pollen quantities of this period stay relatively low (30-40\%), not exceeding those of Betula pollen (40-60\%). From the Otepää pollen profile also BO1 and BO2 zones are described with high contents of Pinus pollen (50$60 \%$ ). In the second half of this zone the percentage of Alnus pollen increases in the L. Juusa pollen profile. In lakes Juusa and Ala-Pika Picea pollen has been found in low amounts $(<1 \%)$ since the Pre-Boreal Chronozone, but in the Otepää core the proportion of Picea pollen is over 10\% already at the end of the Boreal Chronozone.

The border between JU3 and JU4 zones at $875 \mathrm{~cm}$ depth corresponds to the border between the Boreal and Atlantic chronozones, which is confirmed by the ${ }^{14} \mathrm{C}$ dating of this layer at $\sim 7910{ }^{14} \mathrm{C}$ yr BP. The spreading of QM-dominated forests during the climatic optimum is well visible on JU4 in the L. Juusa pollen diagram (Fig. 3), where the percentages of Ulmus (10-20\%), Tilia (10-20\%), and Corylus (5-10\%) are rather high. Later also the percentage of Quercus pollen increased (maximum 15\%). Samples that could be correlated with the Atlantic Chronozone are missing in the L. Ala-Pika profile, but in the Otepää pollen diagram high values are shown by Corylus (15-20\%), Ulmus ( 15\%), Tilia ( 10\%), and Quercus $(<5 \%)$. The content of Picea pollen is relatively high (10-15\%).

The decrease in QM from 40 to $20 \%$ and the increase in Picea pollen to $30 \%$ mark the beginning of JU5 in the L. Juusa pollen profile. On the Holocene stratigraphic chart such a change corresponds to the beginning of the Sub-Boreal 2 Chronozone, defined with the age $\sim 4000{ }^{14} \mathrm{C}$ yr BP. In L. Juusa this change occurs at a depth of $455 \mathrm{~cm}$ (Fig. 3), which is dated at $\sim 5200{ }^{14} \mathrm{C}$ yr BP (Table 2). The great differences in the percentages of Picea pollen in different pollen diagrams lead to the question of when Picea immigrated to the Otepää region. Saarse et al. (1999) showed that the first Picea stands dated to 8000-7500 BP were recorded in southeastern Estonia and the Picea forest front reached the northern coastal area about 5000 BP. As Picea pollen is strongly underrepresented in modern pollen rain, 2-3\% of spruce pollen seems to be sufficient to indicate its establishment (Saarse et al. 1999). In the Otepää pollen profile 
(Sarv 1979) the proportion of Picea pollen exceeded 10\% level already at the end of the Boreal Chronozone. At the same time it was below $1 \%$ in the L. Juusa (Fig. 3) and L. Ala-Pika (Kihno 1998) pollen diagrams. It can be suggested that single Picea stands were present around the Otepää site already earlier, at the end of the Boreal Chronozone, but spread to the surroundings of L. Juusa and L. AlaPika at the end of the Atlantic and beginning of the Sub-Boreal. One reason for low quantities could be long-distance transportation of pollen. A more precise answer to this question could be obtained from macrofossil analysis, because macroremains of Picea can sometimes be found 1000-2000 years earlier than revealed in pollen record (Kullmann 1995). Pollen and macrofossil analysis from the Viitna kettlehole has shown that Picea macroremains are present in $\sim 9000 \mathrm{yr}$ BP old sediments, though Picea pollen in sediments of the same age makes up less than $1 \%$ (Koff \& Kangur 2003). Based on the available data we can conclude that in small portions Picea was present already at the end of the Boreal Chronozone and its wider spread started at the end of the Atlantic Chronozone.

In the Sub-Boreal Chronozone in the L. Juusa pollen diagram of JU5 the proportion of Picea pollen is mostly above $30 \%$, at the end of the zone increasing to $50 \%$ level. In the Otepää and Ala-Pika core No. 2 pollen diagrams the abundance of Picea pollen does not exceed $30 \%$. Modern pollen rain monitoring in southeastern Estonia shows that in spruce-dominated forest the Picea pollen values range from 10 to $20 \%$ (Saarse et al. 1999). According to this information, spruce was highly dominating in the surroundings of L. Juusa during the Sub-Boreal Chronozone.

At the end of the Sub-Boreal Chronozone the percentage of Picea pollen decreases in all studied sites (Table 3). In the L. Juusa pollen diagram the proportion of Picea pollen decreases from 50 to $15 \%$ during a relatively short period. Considering the increase in the charcoal total area, it can be presumed that at the end of the Sub-Boreal Chronozone most of the spruce forests in the surroundings of L. Juusa perished in forest fires.

The PAZs JU6 and JU7 (Fig. 3) represent the Sub-Atlantic Chronozone. In JU6 Betula (pollen $\sim 40 \%$ ) was the dominating tree in the surroundings of L. Juusa. An analogous high percentage of Betula is also estimated in zone B in the L. Ala-Pika core No. 2 (Table 3). Kihno (1998) distinguishes also zone Pc-P in the same core at a depth of 1010-910 cm, indicative of a second Picea maximum. The corresponding zone in the Otepää pollen profile is SA2. A similar PAZ cannot be distinguished in the L. Juusa pollen profile (Fig. 3). During zone JU6 the percentage of Picea pollen stays very low. In the curve of Pinus pollen no major changes are visible either.

Zone JU7 in the L. Juusa profile is characterized by an increase in NAP and Cerealia-type pollen with a simultaneous increase in the total area of charcoal particles. These changes indicate transformations in human activity in the surroundings of L. Juusa. In L. Ala-Pika core No. 2 more herb pollen is present already in the Sub-Boreal, and the diversity of different pollen types is higher in 
the Sub-Atlantic than in the L. Juusa pollen profile. Also species indicative of human activity are represented in the Sub-Boreal Chronozone in L. Ala-Pika pollen profile No. 2 (Kihno \& Valk 1999). In the L. Juusa core similar species appear first in the middle of the Sub-Atlantic. However, at the end of this chronozone the proportion of Cerealia pollen is higher in the L. Juusa profile (10\%) than in the L. Ala-Pika profile $(<5 \%)$.

Comparison of the three pollen diagrams from the Otepää Heights (Table 3) shows that the variety of pollen spectra of different profiles has been increasing since the Boreal. As the studied sites lie very close to each other and thus the general climate trends must have been similar, the differences between the pollen profiles may result from local-scale vegetation development factors. One reason for such differences can be divergences in pedogenesis. Pedogenic processes were very slow until the melting of permafrost at the end of the Late-Glacial. Birch and birch-pine mixed forests started to replace tundra and cryoarid grasslands in the Pre-Boreal, the production processes changed and so did pedogenesis. The content of carbonates in parent rocks, the soil formed during the tundra period, and the moisture regime of soil and the underlying bed began to play the leading role in pedogenesis (Reintam 1995). As the landform variety is very high in the Otepää Heights, also the variety of different soil types is high. From the Boreal Chronozone onward, landscape diversity and speed of pedogenic processes underlie the differences in the compared pollen diagrams. Human impact and forest fires have become the determining factors for vegetation development during the end of the Sub-Boreal and Sub-Atlantic.

\section{CONCLUSIONS}

Pollen analytical investigations of the L. Juusa sediment core and complementary AMS ${ }^{14} \mathrm{C}$ datings show that local PAZs, in principle, correlate well with chronozones in the stratigraphic chart of Holocene sediments in Estonia. There is no doubt that climate has been the main external force determining vegetation development in general. Climate determines which plants are dominating in different time periods on a regional scale. A characteristic feature of the Otepää Heights is mosaic landscape. As lakes are small, and therefore the relevant source area of pollen is some hundred metres around the lake, local-scale factors play an important role in the development of pollen spectra. Such factors could be analysed by comparison of L. Juusa, Otepää, and L. Ala-Pika pollen diagrams (Table 3). All these pollen diagrams are similar before the Boreal Chronozone, but thereafter the diversity between the sites increases. One reason for this may be variability in pedogenic processes. The most characteristic differences are observed in the Picea pollen content. In the L. Juusa profile the increase in Picea pollen starts 1000 years earlier than in the Holocene stratigraphic chart of Estonia (Table 3). The percentages of Picea pollen are very high in the Sub-Boreal Chronozone in the L. Juusa profile. The rapid decrease in Picea pollen in L. Juusa 
(Fig. 3) at the end of the Sub-Boreal is probably a result of forest fires, as the charcoal total area curve increases at the same depth. In L. Ala-Pika core No. 2 percentages of herb pollen are higher and indicator species of human activity increase earlier than in the L. Juusa diagram. However, in the Sub-Atlantic Chronozone percentages of Cerealia-type pollen are higher in the L. Juusa core than in the L. Ala-Pika core. At the same time the pollen diagram of the Otepää core is affected by the overgrowth of the lake and changes in the relevant source area of pollen. The content of Pinus pollen is relatively low and stable in the L. Juusa and L. Ala-Pika cores in comparison with the Otepää core. Forest fires and human activity have also substantially contributed to the development of the L. Juusa pollen spectra during the last two millennia.

\section{ACKNOWLEDGEMENTS}

Financial support of the Estonian Ministry of Education (project No. 0282120s02) and the Estonian Science Foundation (grants Nos. 5580 and 5584) is gratefully acknowledged. The AMS dating was done with support from British Ecological Society (grant No. 2033). Valuable comments and recommendations of the referee Dr. L. Saarse and an anonymous referee are greatly appreciated.

\section{REFERENCES}

Andersen, S. T. 1970. The relative pollen productivity and representation of north European trees, and correction factors for tree pollen spectra. Danmarks geol. Undersøgelse, 96, 1-99.

Davis, M. B. 1963. On the theory of pollen analysis. Am. J. Sci., 261, 897-912.

Hang, E. 1979. Otepää kõrgustiku kõrgussuhted. In Eesti NSV saarkõrgustike ja järvenõgude kujunemine (Raukas, A., ed.), pp. 29-41. Valgus, Tallinn.

Jackson, S. T. 1990. Pollen source area and representation in small lakes of the northeastern United States. Rev. Paleobot. Palynol., 63, 53-76.

Jacobson, G. L. \& Bradshaw, R. H. W. 1981. The selection of sites for paleovegetational studies. Quat. Res., 16, 80-96.

Janssen, C. R. 1973. Local and regional pollen deposition. In Quaternary Plant Ecology (Birks, H. J. B. \& West, R. G., eds.), pp. 31-42. Blackwell, Oxford.

Kabailene, M. 1979. Formation of pollen spectra and methods for the reconstruction of the palaeovegetation. Proc. Inst. Geol. (Vilnius) (in Russian).

Kangur, M. 2002. Methodological and practical aspects of presenting and interpreting microscopic charcoal data from lake sediments. Vegetation Hist. Archeobot., 11, 289-294.

Kihno, K. 1998. Taimkatte areng ja inimmõju ilmingud Lõuna-Eesti mosaiikmaastikus. Master's thesis. Manuscript at TPU Chair of Geoecology.

Kihno, K. \& Valk, H. 1999. Archaeological and palynological investigations at Ala-Pika, Southeastern Estonia. PACT, 57, 221-237.

Koff, T. \& Kangur, M. 2003. Vegetation history in northern Estonia during the Holocene based on pollen diagrams from small kettlehole and lake sediments. In Fest Shrift, Aspects of Paleoecology and Palynology (Tonkov, S., ed.), pp. 113-126. PENSOFT Publishers.

Koff, T., Punning, J. M. \& Kangur, M. 2000. Impact of forest disturbance on the pollen influx in lake sediments during the last century. Rev. Palaeobot. Palynol., 111, 19-29. 
Kullmann, L. 1995. New and firm evidence for Mid-Holocene appearance of Picea abies in Scandes Mountains, Sweden. J. Ecol., 83, 439-447.

Laasimer, L. 1965. Eesti NSV taimkate. Valgus, Tallinn.

Moore, P. D. \& Webb, J. A. 1978. An Illustrated Guide to Pollen Analysis. Hodder \& Stoughton, London.

Parsons, R. W. \& Prentice, I. C. 1981. Statistical approaches to R-values and pollen-vegetation relationship. Rev. Palaeobot. Palynol., 32, 127-152.

Prentice, I. C. \& Parsons, R. W. 1983. Maximum likelihood linear calibration of pollen spectra in terms of forest composition. Biometrics, 39, 1051-1057.

Punning, J.-M., Koff, T., Kadastik, E. \& Mikomägi, A. Holocene lake level fluctuations recorded in the sediment composition of the small dimictic Lake Juusa (SE Estonia). Paleolimnology (in press).

Raukas, A. \& Karukäpp, R. 1979. Eesti liustikutekkeliste akumulatiivsete saarkõrgustike ehitus ja kujunemine. In Eesti NSV saarkõrgustike ja järvenõgude kujunemine (Raukas, A., ed.), pp. 9-27. Valgus, Tallinn.

Raukas, A., Saarse, L. \& Veski, S. 1995. A new version of the Holocene stratigraphy in Estonia. Proc. Estonian Acad. Sci. Geol., 44, 201-210.

Reintam, L. 1995. Muldade kujunemine. In Eesti. Loodus (Raukas, A., ed.), pp. 419-430. Valgus, Eesti Entsüklopeediakirjastus, Tallinn.

Saarse, L., Poska, A. \& Veski, S. 1999. Spread of Alnus and Picea in Estonia. Proc. Estonian Acad. Sci. Geol., 48, 170-186.

Sarv, A. 1979. Structure and Stratigraphy of Quaternary Deposits, Holocene. Structure and Formation of Accumulative Insular Heights in South-Estonia. Vol. 1, pp. 210-216. Institute of Geology, Academy of Sciences of the Estonian SSR, Tallinn (in Russian). Eesti Riigiarhiiv (unpublished manuscript).

Stockmarr, J. 1971. Tablets with spores used in absolute pollen analysis. Pollen Spores, 13, 615621.

Stuiver, M., Reimer, P. J. \& Bard, E. 1998. INTCAL98 radiocarbon age calibration, 24 000-0 BP. Radiocarbon, 40, 1041-1077.

Sugita, S. 1994. Pollen representation of vegetation in Quaternary sediments: theory and method in patchy vegetation. J. Ecol., 82, 881-897.

Sugita, S. 1998. Modelling pollen representation of vegetation. In Quantification of Land Surface Cleared of Forest During the Holocene - Modern Pollen/Vegetation/Landscape Relationships as an Aid to Interpretation of Fossil Pollen Data (Gaillard, M.-J. \& Berglund, B. E., eds.). Paläoklimaforschung/Palaeoclimate Res., 27, 1-16.

Tauber, H. 1965. Differential pollen dispersion and the interpretation of pollen diagrams. Dan. Geol. Unders., 2, 89, 1-69.

\section{Otepää kõrgustiku Holotseeni järvesetete palïnostratigraafia}

\section{Mihkel Kangur}

Esimene Otepää kõrgustiku alalt kogu Holotseeni hõlmava järvesetete läbilõike õietolmudiagramm, mis on radiosüsinikumeetodil dateeritud, annab ülevaate üldisest taimkatte arengust regioonis. Väike Juusa järve läbilõike õietolmudiagrammil eristatud lokaalsed õietolmutsoonid vastavad põhijoontes Eesti metsade üldisele arenguskeemile. Võrreldes Juusa järve õietolmudiagrammi Otepää ja 


\begin{abstract}
Ala-Pika omadega, on taimkatte arengus võimalik eristada lokaalsetest tingimustest mõjutatud erinevusi. Tulenevalt võrreldavaid läbilõikeid ümbritsevate alade geoloogilis-geomorfoloogiliste tingimuste mitmekesisusest ja hüdroloogilisest režiimist, toimub alates Boreaalsest kronotsoonist taimkatte arenguteede diferentseerumine. Kõige ilmekamalt on erinevused jälgitavad kuuse õietolmusisalduses. Kuusk ilmub Otepää kõrgustiku aladele väikeste rühmadena ilmselt juba Boreaali 1õpul, kuid ulatuslikum laienemine toimub Atlantilise kronotsooni lõpul. Väike Juusa järve õietolmudiagrammil algab kuuse õietolmusisalduse suurenemine ligikaudu 1000 aastat varem kui Eesti Holotseeni setete stratigraafilisel skeemil. Subboreaalses tsoonis ilmnevad võrreldavatel diagrammidel kuuse õietolmusisaldustes märgatavad erinevused. Männi õietolmusisaldus jääb kogu läbilõike ulatuses tagasihoidlikuks, seda isegi Boreaalses tsoonis, kus enamasti esineb männi õietolmusisalduse esimene maksimum. Lokaalsete taimkatte arengut mõjutavate faktoritena saab käsitleda ka inimmõju ja metsatulekahjusid, mille ajalugu on võrreldavate läbilõigete ümbruses samuti erinev olnud.
\end{abstract}

